\title{
Migration, Environment and Public Health: Theory and Interdisciplinary Research from a Regional Science Perspective
}

\author{
Nikias Sarafoglou ${ }^{1}$, Menas Kafatos ${ }^{2}$, William A. Sprigg ${ }^{3}$ \\ ${ }^{1}$ George Mason University, Arlington, Virginia, USA \\ ${ }^{2}$ Chapman University, Orange, California, USA \\ ${ }^{3}$ University of Arizona, Tuscon, Arizona, USA \\ Correspondence: Nikias Sarafoglou, George Mason University, Arlington, Virginia, USA.
}

Received: February 14, 2016

Accepted: March 14, 2016

Available online: March 20, 2016

doi:10.11114/ijsss.v4i4.1473

URL: http://dx.doi.org/10.11114/ijsss.v4i4.1473

\begin{abstract}
As regional climate evolves into new climatic states in different parts of the world, humanity will be facing increasing issues associated with migration environment and health concerns. Challenges of major hazards and impacts on human societies, involving water resources, agriculture, economy and energy issues are central issues. This paper examines the generalization of Tiebout's model in our understanding of the forced environmental migration of the Great Planes farmers to California during the Dust Bowl period in 1931-1939. The paper considers the issues of public health that arose from this migration after the arrival and settlement of the Okies in California. Settlement of the migrants in California was more bitter than the migration itself, prompting John Steinbeck to write his award winning novel of the journey in the "Grapes of Wrath." Among many health risks in their new environment a relatively unappreciated and unpublicized airborne fungus causing Valley fever when inhaled emerged. Valley fever was, and is today, highly endemic in California's San Joaquin Valley where many of the Okies remained, staying for employment in agriculture and working the fertile soil that harbored the fungus. The vast majority of migrants into the San Joaquin Valley had been infected, but we know today that most who were, did not report it. A very high percentage of migrants did become infected when a few statistics emerged, such as $25 \%$ of the population of one migrant camp were diagnosed with the disease. Many migrants fought the disease only to die later in the 1940s and 1950s. The destiny of the migrants was not exposed in books or mass media until the early 1960s. Many migrants escaped infection when they left the fields for employment in the factories and manufacturing supporting the World War II effort. Other reasons for this historical silence were the Great Depression, those who went to war, the Cold War era, and the Californian farmers themselves who kept the infection secret. The second generation migrants or the "survivors" from Valley fever infection exposed the destiny of their parents in the Californian farms in the mass media in the early 1960s and later on Internet webpages and blogs in the 1980s. We examine the general implications and lessons learned from these historical cases.
\end{abstract}

Keywords: Dust Bowl, environmental migration, Tiebout's model, public policy, public health, Valley Fever virus or Coccidioidomycosis, propagation of ideas.

\section{"Migration, Environment and Public Health: Theory and Interdisciplinary Research from a Regional Science Perspective"}

"The land is so much more than its analysis," John Steinbeck

\section{Introduction}

John Steinbeck's magnum opus, The Grapes of Wrath (1939), was based on the record of environmentally forced migration from Oklahoma to California in the 1930s during the Great Depression. Oklahoma and certain neighboring states experienced the famous "Dust Bowl," which has been analyzed by atmospheric scientists, agronomists, and geologists with respect to storms, precipitation, crops, and soil erosion. The economic consequences of the Dust Bowl were enormous and bitter, particularly for the landowners and agricultural workers. President Franklin D. Roosevelt described the situation of the farmers and stockmen in his speech (1936):

No cracked earth, no blistering sun, no burning wind, no grasshoppers are a permanent match for the indomitable 
American farmers and stockmen, and their wives and children who have carried on through desperate days and inspire us with their self-reliance, their tenacity, and their courage.

For most of the population environmental change was too strong and migration west was the only perceived solution for the regional Dust Bowl calamity.

In early American history, the West had a lower population density and higher income per capita than any other US area. Hotelling's (1921) population growth and migration model was based on these two historical observations. He used the mathematical representation of pressure and gradients to articulate the idea of migration flows. More than a half million workers "flowed" to California with an eye on finding employment in the fertile San Joaquin Valley. Steinbeck's protagonists moved to the Bakersfield area in the San Joaquin Valley. After the initial shock of hard economic and social dislocation, the migrants eventually obtained work in agriculture and were eventually assimilated into California society. However, in the interim migration was not a "happy ending" for many Dust Bowl migrants. Many were infected by a variety of diseases, including tuberculosis, scarlet fever, and whooping cough, made worse by their poverty and cramped living conditions during the move and after their arrival.

A complicating factor was a relatively unknown illness called Valley Fever or Coccidioidomycosis, from which a sizable number of migrants died in the years following the mass migration. Public Health scientists in endemic regions tried to help the infected migrants during the Great Depression and World War II periods. See, for instance, the Kern County Public Health Services Department's comprehensive webpage for the illness: "kerncountyvalleyfever.com".

To understand the Dust Bowl migration requires the attributes of multidisciplinary network analysis to appreciate the complexity of the environmental and social disaster: atmospheric science, geology, agronomy, public policy, humanities, sociology, economics, geography and public health, all of which provide insight into this population transformation (Steinbeck, 1939; Hirschmann, 2007; Potter, 2013; Galgiani, 2008; Pappagianis and Einstein, 1978; Davis, 1998; and Sprigg, et al., 2014).

At an even wider scale. Linkages between environmental change and social consequence, we provide examples of pre-historic migration of humans. In order to analyze this pre-historic migration, DNA-research has been applied widely as a tool for tracing these movements. Mapping the genetic record of Homo sapiens, provides an understanding of the pattern of this migration from Africa to Europe, Asia, and to Australia and the Americas 60,000 years ago. If we consider the genealogical past of American Indians, DNA information reveals an ancestry of people that migrated from Asia some 50,000 years ago. Also DNA patterns are at least partly verified by paleontological records. See, for example, the work of Danish evolutionary biologist Eske Willerslev, reported by Dalton (2010). Strong ongoing DNA-research traces this global migration. See, for example, the Genographic Project (2005), a research partnership of IBM and the National Geographic (genographic.nationalgeographic.com or ibm.com). Such work was further bolstered when the Nobel Prize in Chemistry was awarded in recognition of the credibility and power of DNA analyses.

It is clear that migrations at the micro-, meso-, and macro-levels deserve careful evaluation, but it is also clear that its full appreciation is not limited to the social sciences.

The study of migration is multi-disciplinary by nature, encompassing scientific (physical, natural and social sciences) as well as humanitarian (historical and cultural) dimensions. Yet, poor communication both between and within disciplines is a recognized issue, even today's technological world. Molho (2013) wrote:

"A longstanding and deeply rooted problem in assimilating and evaluating research on migration theory lies in the diverse and fragmented nature of the field. As a result, reliance on any one single approach will likely lead to a highly specific and incomplete view of the complex process behind individuals' locational decisions in the space economy."

In other words, reliance on any single discipline is likely to yield only partial-insights. Indeed, the use of any one-discipline and fragmented approaches for understanding complex processes like migration leads to incomplete and in some cases incorrect conclusions. Koopmans (1979) argued that the gradual breakdown of barriers between disciplines and their respective approaches would advance science, and the science of migration is an example where that comment seems particularly pertinent.

Due to fragmentation, Tiebout's theory of migration (Tiebout, 1956) potentially appears to be a key missing element. Tiebout's "pure theory" of location choice is one of the most cited articles in public and regional policy, but it is almost forgotten/overlooked in migration surveys. Clearly, "The act of moving or failing to move is crucial. Moving or failing to move replaces the usual market test of willingness to buy a good and reveals the consumer-voter's demand for public goods" (Tiebout, 1956). According to Kurt Lewin's, (1951) aphorism "There is nothing so practical as a good theory." A good theory can generate rules of correspondence that connect the theory's main insights with applied or empirical research. Given the assumption that the Tiebout (1956) hypothesis is good migration theory, the present study traces the empirical applications thereof that verify his theory as we proceed with this survey. 
Underlying idea in this survey has been a synthesis of a short distance migration framework based on the original interpretation of the Tiebout (1956) hypothesis with a long distance migration based on Steinbeck (1939). Whereas the first issue, the Tiebout (1956) hypothesis is well-known and in both its initial and expanded forms and is well researched, this paper focuses on a specific survey direction (the so-called scientometric propagation of scientific thinking). The latter has been largely un-researched by regional scientists, especially after the migrants' arrival in California. In section 1 of the present study, we highlight the most important contributions and controversies of migration research across the social sciences by using bibliometric or scientometric evaluations of migration surveys based on Garfield's work (Garfield.library.upenn.edu) on the propagation of scientific thinking. (Garfield initiated the old "Science Citation Index, the forerunner of the modern equivalent "Web of Science" database). Public policy implications of Tiebout's theoretical model (1956) are discussed in section 2. In section 3, we analyze a public health dimension of the Dust Bowl migration in California in 1930's as a contributor to our understanding of this complex process.

\section{Approaches to Migration}

The social sciences migration bibliographies and surveys might be by definition "partial" because of the interdisciplinary nature of the subject. We refer to the following: the annotated bibliography from Price and Sikes (1975) and the works in economics by Greenwood (1975 and 1985), Greenwood. et al. (1991), Cebula (1979, Chapter 10), Cebula (1980), Ghatak (1996), and Molloy et al. (2011) for migration in America; the Todaro (1969) survey for less developed countries (1976); and Molho's review (2013) for Europe. In sociology, the Ritchey survey (1976) is noteworthy also.

The U.S. statistical data on migration are based on decennial censuses, surveys and lately on the "national longitudinal survey of youth." Greenwood (1975) in his well-known survey of migration literature considered nearly 250 references and had the following general configuration (Figure 1).

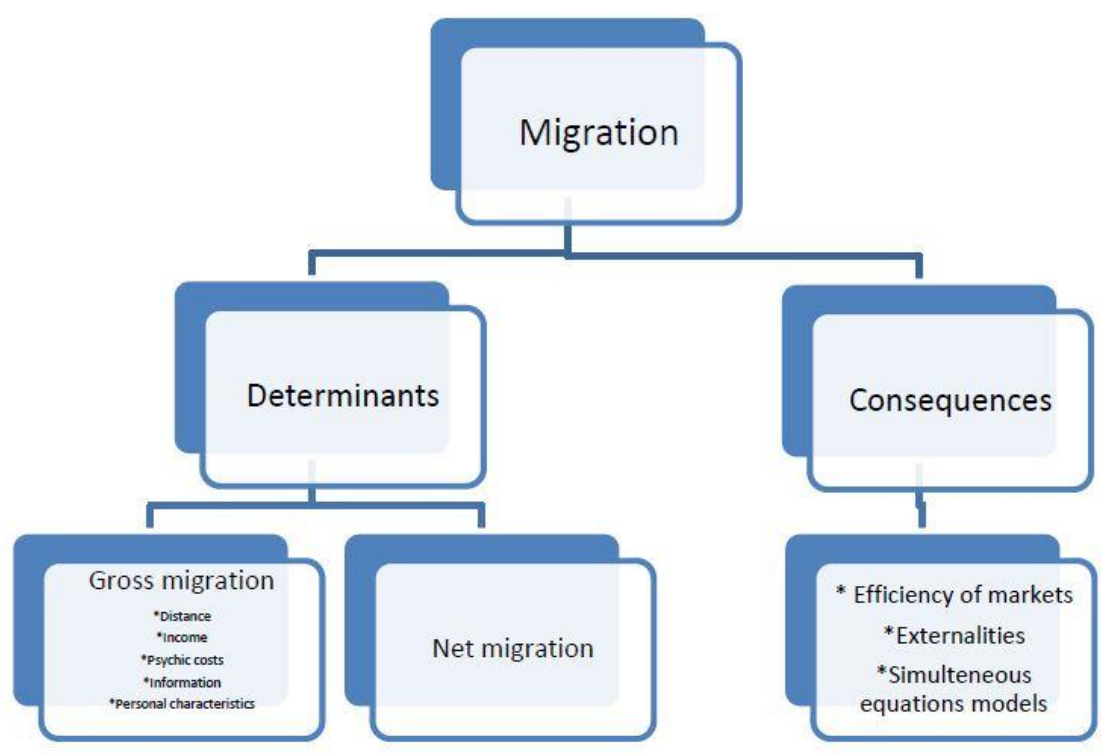

Figure 1. Greenwood's Configuration of Migration

The principal conclusion in Greenwood (1975) is that the social science/economics migration literature has focused excessively on the determinants and not on the consequences of migration, while noting the importance of the multidisciplinary nature of the work, "Not only economists, but also demographers, sociologists and geographers have made numerous contributions to the migration literature since 1960" (Greenwood, 1975). His references have had wide variations in terms of their citation impact during the 40 years since publication (Figure 2). 

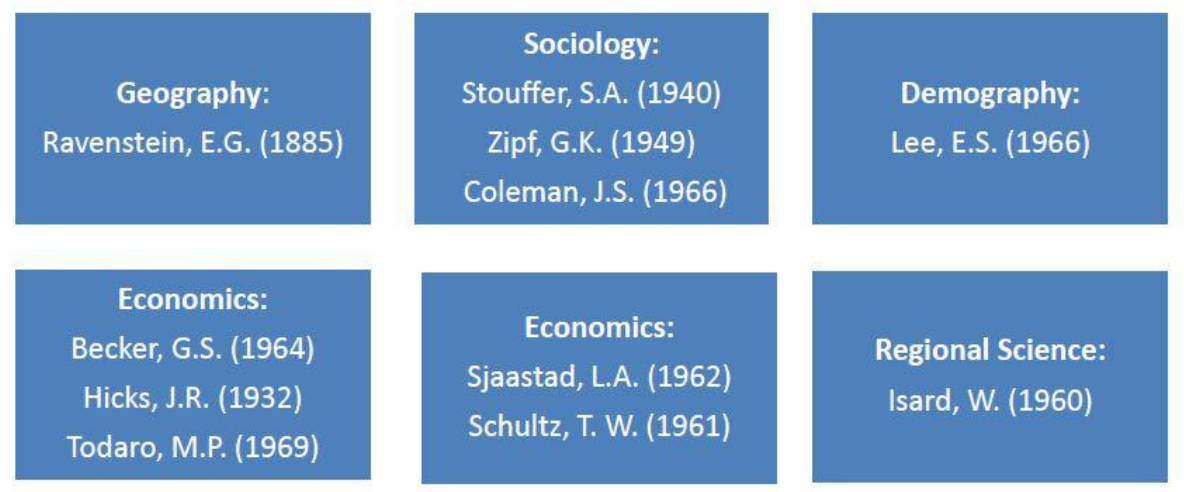

Figure 2. High impact references in Greenwood's survey (1975) by subject

\section{Source: Web of Science}

Herein we extend Greenwood's migration view based on partially expanding the interdisciplinary literature in social sciences. For example, the geographer Ravenstein (1885) may be regarded as one of the founders of migration analysis with his seminal papers published in the Journal of the Royal Statistical Society. In these papers he formulated a comprehensive theory of the determinants of migration. Since then, many scientists from different disciplines theorize about the complex interrelationships between migration and economic, social and psychological factors.

Hicks' publication (1932) has played a vital role in migration studies that followed, particularly in contributions in economics. His argument was that wage differentials between regions are the main cause/driving factor of migration has been of central importance even though he did not distinguish between real and nominal wages.

The next important theoretical approach was the gravity, or spatial interaction, model partially developed in the Ravenstein's migration model but thereafter extended significantly. In early use the migration system is considered to be similar, conceptually, to a celestial system. Population size in a migration field acts like a mass in a gravitational field. Numerous studies of migration have been based on this de facto Newtonian paradigm. It will suffice to mention the derivation of the potential models by Stouffer (1940) and Zipf (1949), which were published in sociology journals. Later in the 1950s, the gravity model was broadened and generalized by integrating demographic variables with economic variables, such as job vacancies, wages, employment and income. In the 1960s, simultaneous equation models were used to quantify migration determinants and forecast population. The search for regularities is a central theme in the Newtonian model of Science as well as in our own picture of the world. Frisch (1969) stated in his Nobel Prize lecture in economics, "Indeed, science too has a constant craving for regularities. Science considers it a triumph whenever it has been able by some partial transformations here and there, to discover new and stranger regularities." Due to lack of predictability at the individual level, combined with the large numbers of individuals, regularities appear only to be observed in the aggregate behavior of the human beings. Although, since then, micro-behavior has been linked to these macro perspectives using probability theory, entropy modeling, and information theory. In the social sciences, this principle can be traced back to Quetelet's work "Social Physique" in 1835. Scientists built models "theories in manipulative form," for describing population distribution and economic development.

Isard's vision of and contribution to Regional Science in the 1950s had an integration effect on the communication and collaboration in social sciences, especially among the disciplines of economics, sociology, anthropology, psychology and geography. Migration had a spatial definition, because migration involves movement over space, and every space represents a unique distribution of opportunities, transport costs and search information costs. Isard (1960) defined "Regional Science" as a discipline concerned with "...the careful and patient study of social problems with regional or spatial dimensions," such that it could be considered a common platform for migration research.

The Nobel Prize winners Becker (1962) and his co-worker at the University of Chicago, Coleman (1956) had a very visible impact on migration literature. According to Becker (1962), the migrant evaluates his expected utility when making a migration decision. Not surprisingly, Becker's "human capital theory" was equally important in "education economics" and migration theory.

Sjaastad (1962) in his classic article noted, “... little has been done to determine the influence of migration as an equilibrating mechanism in a changing economy." In Demography, a popular approach to migration is the multiregional demographic model, based both on Lotka's stable population theory, Markov's assumption, and Leslie's matrix model (Sarafoglou, 1987).

Greenwood (1975) cited Isard's (1960) work in Regional Science, as the "father" of Regional Science. In the book by 
Isard and Liossatos (1979), the "green book," a non-Newtonian dynamics framework for spatial dynamics was introduced. Interestingly, Donaghy (2002), in his article "The "green book, twenty years on" argued that "the book has begotten little secondary scholarship" because of its mathematical complexity.

Another group of scientists from Stuttgart University, under the leadership of W. Weidlich, started a parallel migration research activity by using statistical physics, e.g., Master equation (a stochastic differential equation), for migration independently from Isard-Liossatos. Weidlich (1991) used concepts from Synergetics for population dynamics. This field developed in theoretical physics by Hermann Haken (1981) also in Stuttgart. Synergetics is based on "self-organization of non-equilibrium systems." Weidlich and Haag (1983) and Weidlich (2000) had a higher impact in Master equation applications in migration systems than even the father of regional science, Isard (Holmberg and Sarafoglou, 1988).

Using the Sociology of Knowledge, the efforts of Isard-Liossatos and Weidlich could be classified as "multiple discoveries," but we know from the history of multiple discoveries that one of them usually becomes more dominant than others in terms of recognition (Sarafoglou, Kafatos, and Beall 2012).

The migration-concept of a "spatial choice set" introduced by regional scientists (Greenwood et al., 1991) was implemented in experimental economics (Lieber, 1979).

The enormous evolution of modern migration research since Ravenstein's work has been based on four components: 1 . Population data (quantity and quality), 2. Statistical and mathematical methods, 3. Software development, and 4. Computer capacity. Finally, the isomorphism between social, physical or natural sciences in migration research is obvious. The initial gravity models with simple Newtonian dynamics have been gradually replaced by stochastic models with more sophisticated non-Newtonian dynamics via information theory and Luce's choice theorem of behavior.

\section{Public Policy and Migration: The Tiebout Hypothesis}

Tiebout was Musgrave's student at the University of Michigan in the early 1950s. Samuelson's article (1954) "A pure theory of public expenditure" was the inspiration for his work on "A pure theory of local expenditure" (1956). In his article, Samuelson could not determine the optimal allocation of resources towards private versus public goods: "No decentralized pricing system can serve to determine optimally these levels of collective consumption." The student Tiebout tried to solve Samuelson's problem by using local public goods and migration. Tiebout died in 1968 at the age of 43. He was not a prolific author, but his work had very impact values. His 1956 article in Journal of Political Economy is one of the most cited articles in regional policy with more than 3,300 citations in scholarly journals according to the bibliometric database Web of Science.

His life-time citation score is approximately 4,000 citations (Web of Science), which means that his 1956-student-paper was an extraordinary achievement. Tiebout wrote a regional economics dissertation, which was accepted in 1957 at the University of Michigan. Although he had a strong background in public finance, he preferred to work more in regional science than public finance during his short research career (1957-1968). Walter Isard's newly established regional science in the 1950s was more attractive to him than Richard Musgrave's traditional public finance.

Tiebout's 1956-paper had a very slow citation growth cycle in the1956-1965 period. The paper received 7 citations during the first decade after the publication. State and local finance was not a popular research theme in the 1950s and 1960s. In the Cold War era, one might expect the state and local administration to be more popular than federal administration and national planning, given Leontief's applications. To the contrary, however, the Washington DC central decision-making was very strong during this period in the US (Fischel, 2006). Political scientists considered this era of rising "supremacy of the centralized government."

The citations for Tiebout's paper (1956) increased dramatically after Oates' (1969) publication of property tax analysis based on the term coined as the "Tiebout hypothesis". Home-ownership, property taxes, and property values were important to any American. Keynesianism and the "grand" government lost importance for the voters in the 1970s. Microeconomics research gained popularity at the cost of macroeconomics and stabilization policy research agendas. The associated local government research gained momentum.

The intellectual relation between Oates (1969) and Tiebout (1956) can be seen as a source of a great philosophical discussion. Although Tiebout had not mentioned property taxes and property values in his paper, the "Tiebout hypothesis" became the cornerstone for local property tax capitalization. Tiebout's tax is a head tax. By introducing taxes on land rents or property taxes and property tax capitalization into the Tiebout model, the model becomes more realistic but also more complicated (Tullock, 1971; Cebula 2002; 2009; Coombs, Sarafoglou, and Crosby, 2012). Indeed, Oates' addition to Tiebout's ideas was in itself a major contribution.

This Oates-interpretation of Tiebout recalls the old debate between "Keynesian Economics" and the "Economics of Keynes." Was the "IS-LM model" a pedagogical instrument for students to understand the Keynesian thought, or was 
the "IS-LM model" a mathematical formulation consistent with the "General Theory?" This IS-LM discussion generated thousands of journal and book pages, but the Axel Lejonhufvud's seminal work (1968) is worth noting for his Keynesian synthesis.

If Oates (1969) catalyzed the 'take off' citation process of Tiebout's paper, the next most influential citations came from the political scientists Vincent and Elinor Ostrom (1971) and the environmentalist Lester Thurow (1971). Elinor Ostrom won her Nobel laureate for "her analysis of economic governance, especially the commons," which of course links back to Tiebout's work on local property tax and individual immigration chain behavior.

The second Tiebout citation "take off" took place in 1974, after Henderson's paper on "types of cities" with approximately 300 citations and Rosen's paper on "hedonic prices" with more than 2,300 citations. Buchanan's citation in 1975 in "public choice" solidified the importance of the Tiebout hypothesis. Buchanan's Nobel award cited "his development of the contractual and constitutional bases for the theory of economic and political decision-making."

During the first period of citations of Tiebout's work, (1956-1975), the "hypothesis" was cited 96 times according to the Web of Science. The eponymous citations of the first period generated sufficient dynamics for a set of new citations in the next 40-year period.

Another older philosophical explanation of Tiebout's interpretation with respect to taxes and public goods by other scholars might be similar to Plato's "Allegory of the Cave" in his "Republic." According to this allegory, prisoners isolated in a cave with limited lighting could see the shadows of the objects and tried to identify them. This allegory symbolizes the constraints of human knowledge in relation to reality.

The Physics Nobel laureate Steven Weinberg used Plato's allegory of the cave to describe the development of nuclear physics in the 1960s: We have not been able to get out of this cave, but by looking long and hard at the shadows on the cave wall, we can at least make out the shapes of symmetries, which, though broken, are exact principles governing all phenomena, expressions of the beauty of the world outside. (Baggott, 2011)

The political dimensions of Tiebout's theory were also controversial. Many political scientists considered his theory as a "manifestation of a libertarian-conservative approach to government." The truth is that both Tiebout and Tiebout's family had strong democratic perspectives!

The well-known aphorism, "There is nothing so practical as a good theory," has multiple "fathers," including Maxwell and Lewin. The physicist James C. Maxwell (1831-1879) is cited by mathematicians and Kurt Lewin (1951) is cited by psychologists and social scientists. The French mathematician Henri Poincare (1854-1912) was in the same spirit with Maxwell and Lewin: “...le souci du beau nous conduit aux memes choix que celui de l' utile." A good theory can generate rules of correspondence that connect the theory's main insights with the applied or empirical research. Publications with labels "basic" or "pure" are flagship articles in any journal. On the contrary, labels "applied", or "empirical" have lower status in the publisher's world. "The reverential portion recognizes the power of theory to achieve parsimonious understanding and to guide useful applications-precisely the wisdom of Lewin's statement" (Greenwald, 2012).

Tiebout's pure theory is an example of Maxwell's and Lewin's quote and has generated thousands of empirical works!

Citations in economics and regional science are the most frequent, but citations in political science, environmental studies and law are also important for the Tiebout citation profile. For the convenience of the reader, refer to Table 1 for citations figures by subject area for the period 1956-2014. 
Table 1. Tiebout (1956) citations during the period 1956-2014 by subject area

\begin{tabular}{lcc}
\hline Economics... & 1390 & Citations \\
\hline Urban studies & 524 &.. \\
Political science & 467 &.. \\
Environmental studies & 441 &.. \\
Law & 412 &.. \\
Public administration & 261 &.. \\
Planning development. & 217 &.. \\
Geography. & 185 &.. \\
Business finance. & 177 &.. \\
Social sciences & 67 &.. \\
interdisciplinary. & & \\
Sociology & 66 &.. \\
Education research & 65 &.. \\
International relations & 50 &.. \\
....................... & $\ldots$ &.. \\
Total citations & 3300 & \\
\hline
\end{tabular}

Tiebout's hypothesis (1956, p. 418) is that "The consumer voter may be viewed as picking that community which best satisfies his preference pattern for public goods. ... Given these revenue and expenditure patterns, the consumer-voter moves to that community whose local government best satisfies his set of preferences."

This preference pattern for migration decision-making can be based on public goods benefits combined with liabilities, most often in the form of taxes. Tullock (1971) was in the same navigation direction as Tiebout. Tiebout accepted Samuelson's definition (1954) of a public good: no individual consumption of such a good subtracts from another's consumption of that good. The arguments in Tullock (1971, p. 917) paralleled Tiebout (1956) but were arguably a bit more "realistic," as revealed by his words to the effect that "...the individual deciding where to live will take into account the private effects upon himself of the bundle of government services and taxes." Moreover, extensions of the Tiebout (1956) framework on a larger scale came to include income taxes and formal estimates of "fiscal surplus" (Cebula and Alexander, 2006; Conway and Houtenville, 1998; 2001; 2003; Gale and Heath, 2000).

\section{Dust Bowl and Health; Public Health Issues}

Let us return to the case of Valley Fever, when little was known of its origin and many of its symptoms mimicked the flu, pneumonia or tuberculosis. Unknown at the time, but well established today, the disease is traced to a fungus in soil that experiences seasonal swings between precipitation (for growth) and heat and drought that creates small fragments, (2-5 $\mu \mathrm{m}$ in length), of the brittle fungus that are inhaled. Most victims typically recover after a few weeks of shortness of breath and feelings of exhaustion. But, many others regress to a state of debilitating weakness, including scarring of the lungs and lesions on the skin. To some, the disease is actually fatal (Smith, 1940; Pappagianis and Einstein, 1976). Would these migrants have chosen another destination if these facts were known?

Highly endemic areas for Valley Fever (coccidioidomycosis, or “cocci”) include California's San Joaquin Valley, from which the malady derives its name, and south and east along a broad swath of territory along both sides of the US-Mexico border, through Central America and deep into South America (Laniado-Laborin, 2007). Overall, even today throughout the endemic region, cocci surveillance is poor. Yet, some statistics give us an idea of the seriousness of the disease. On average, 150,000 people in the U.S. were estimated to have contracted Valley Fever annually between 1990 and 2008, with an annual average of 161 deaths attributed to cocci (Huang, et al., 2012). Most of these cases are unreported because initial symptoms are not severe and normal resistance prevails over time. Most documented cases come from the U.S. especially from Arizona where, in 2007, approximately 3,000 cases were reported (there were 6000 cases reported nation-wide), with an associated 1735 hospital visits and $\$ 86$ million in hospital charges (ADHS, 2007, 2010; Tsang, et al., 2010).

In California, Pappagianis (1994) documented increases in cocci cases from 1991 to 1993, and Flaherman, et al. (2007) 
find an average of 70 deaths each year from Valley Fever between 1997 and 2008. Medical records for Kern County, California, attribute approximately $\$ 45$ million in direct costs for hospitalization and outpatient care for Valley Fever cases during the period 1991-1993 (CDC, 1994). Bakersfield, a destination city for Dust Bowl migrants, is in Kern County. And, Kern County shares much of the San Joaquin Valley.

Only recently, in 1997, were physicians in the US required to report a diagnosed case of cocci (ADHS 2012). Methods of laboratory blood tests for cocci have changed over time, and the time-dependent record of surveillance for cocci is poor (Sprigg, et.al, 2014). Medications administered, as an anti-fungal therapy, for Valley Fever depend on the body's immune system to fight the cocci fungus, and treatments are most effective when diagnosis is quick and accurate. However, the several weeks of incubation between exposure and first observed symptoms, and symptoms that often appear too minor to see a physician, contribute to the aforementioned health statistics.

Unfortunately, an obvious risk avoidance method, vaccination, is not available. Uncertainties about the extent of infection with the disease have contributed to this. Windblown dust, some of which may contain the cocci fungus, can fly hundreds of miles (see, e.g. Pappagianis and Einstein, 1978; Marx, et al., 2009). This circumstance, along with revelations of professional athletes contracting Valley Fever while training in the endemic zones and Valley Fever being reported well outside the "endemic zone" (CDC, 2001) tell us that the disease is not confined to a small region.

There are many "ifs" associated with the condition/disease: if cocci is perceived to be contained within a region; if the perceived number of victims having contracted the disease, or those at risk, is too small to offset the costs of research, development and clinical trials of a vaccine; if the associated costs for lost wages and hospital stays are not counted and verified, all of which are perceptions without facts that stifle any incentive to produce a vaccine.

Yet, research shows that a vaccine is, indeed, possible (Cole, et al., 2004; Galgiani, 2008) and perhaps a change in the conventional business model for vaccine development should be modified, as Galgiani suggests. That said, it is interesting to note that only until the 2014 outbreak of Ebola in West Africa produced a sufficient number of victims for potential human clinical trials were pharmaceutical companies given the incentive to rush into developing a counter for the virus, which had now found a way to escape to anywhere in the world (Loftus, P. and B. McKay, 2014). The private industry had been slow to invest, when prior outbreaks were limited in scale and the virus believed confined within poor countries.

Other risk reduction measures, unavailable back then to the Dust Bowl migrants, include public education to avoid airborne dust, to recognize symptoms of Valley Fever, and to seek a doctor's help early if one suspects infection. Successful identification, mapping and monitoring of dust source regions using NASA satellite systems (Morain, et al., 2005; Mahler, et al., 2006; Yin, et al., 2007;) and prediction of dust storms (Sprigg et al., 2012; Vukovich, et al., 2014) and of weather related dust-laden air (Sprigg, et al., 2008) offer further opportunity to reduce risk of infection (Sprigg, et al., 2014).

It may take an international partnership between industry and governments to solve or significantly reduce the problem of Valley Fever, mutually investing in risk avoidance measures, to "promote the general welfare," a purpose of government. Long-term views are needed, as important questions arise because the cocci fungus is so linked to variability of weather and future climates - and to how society responds. Will deserts and the range of cocci expand or "migrate" to additional unsuspecting populations? Employment in solar energy fields has become a new, high-risk occupation for cocci (Cal/OSHA, 2014); in this growing industry will new "migrant" workers from non-endemic areas be especially vulnerable?

Movement from the cities to the suburbs has had a strong environmental component. People often have moved from cities to the suburbs for a "green and clean" environment. However, combined with poor soil management practices, the meteorological and climatological forces behind the dust bowl were too large in scale to be solved other than by long distance migration, to a more benign and hospitable climate. Yet, a climate that harbored cocci, a debilitating disease, can be useful as an example in recognizing the risks and uncertainty surrounding migration decisions. Isard's recognition of the importance of spatial dimensions in understanding migration is paramount in this case and will be in anticipating future migrations stimulated by climate change.

The vast majority of migrants into the San Joaquin Valley had to have been Valley Fever infected, but we know today that most who were, did not report it. A very high percentage of migrants did become infected when a few statistics emerged, such as $25 \%$ of the population of one migrant camp were diagnosed with the disease. Many migrants fought the disease only to die later in the 1940s and 1950s. The destiny of the migrants was not exposed in the books or mass media until the early 1960s. Many migrants escaped infection when they left the fields for employment in the factories and manufacturing supporting the World War II effort. Other reasons for this historical silence were the Great Depression, those who went to war, the Cold War era, and the Californian farmers who kept the infection secret. The second generation migrants or the "survivors" from Valley fever infection exposed the destiny of their parents in the 
Californian farms in the mass media in the early 1960s and later on Internet webpages and blogs in the 1980s.

We may expect migration to lag slowly behind environmental triggers such as climate, which is global in context yet manifested in turbulent, often counter intuitive, regional variability. The mathematician and meteorologist, L. F. Richardson (1922), put it another way, "Big whirls have little whirls that feed on their velocity, and little whirls have lesser whirls and so on to viscosity" of science having a craving for regularity. Yet we often see that "regularities appear only to be observed in the aggregate."

Economic and social anchors are strong, and nature is complex. Environmental predictions are problematic, reminding us again of Plato's allegory of the cave. The situation leaves us open to arguments to ignore the too slowly emerging "shadows on the wall." Future, climate-change induced migrations, in this case, will be complex, fragmented, depending on the distribution of economic and social anchors and perceptions of environmental change, both of where one begins the journey and where one ends it. The Okies migrating from the Dust Bowl surely did not understand the latter. Regardless, the underlying public health issue will likely be especially problematic in the case of migration in LDCs, which have limited information distribution. The parallel in social and economic systems is striking, as in the economist Frisch's (1969) interpretation systems and which involve potentially very large migration flows.

The Dust Bowl migrations and the recent Katrina migrations generate major socio-economic challenges of environmental nature. Cynthia Crossen (2005) explained the term "Environmental Refugees" in the Wall Street Journal. Natural disaster was the main reason for these migrations, but the infrastructure was different.

The historian from Oklahoma Sue Schrems (2010) described the fiscal differences between Dust Bowl and Katrina migrations:

There are a lot of differences between those displaced by the environmental disaster caused by drought and dust storms, and those displaced by Hurricane Katrina. For one, once the mechanisms of government started to offer aid to hurricane victims the suffering began to subside. Those who are benefiting from government aid and relief in 2005 can thank the environmental disaster of the early 1930s. Americans learned from the anguish of Dust Bowl refugees that we all have responsibility, whether through tax dollars, giving to charitable and humanitarian organization, or as volunteers, to aid fellow Americans. This was not the case in 1930.

Californians were very concerned about the "Thousands of indigents from the Middle West" flooding into their state and causing "increasing relief burdens." Los Angeles officials noted that in one twelve-month period 2,946,614 people entered California by automobile. The relief cost in Los Angeles county had increased three-fold in a few short years. Conferences were called where state and city officials came together to discuss the impact of the "indigents" on the state. Besides the obvious strain on meager relief funds, epidemics and the general "character" of the new immigrants were also of concern.

It was not in the American mind in the early 1930s to "hand out" financial relief to those who were unemployed. The thought being that the recipient of the funds would become lazy and lose their will to take care of themselves and their families. It took the Economic Depression of the early 1930s and an environment catastrophe, as witnessed in the Southern Plains, for President Franklin D. Roosevelt and his administration to experiment with various ways in which the Federal government could offer aid to the millions of Americans in need. The results of those programs were born out of necessity.

There is much talk today in the aftermath of Katrina to whether it is wise to rebuild New Orleans so that those who evacuated can return to their homes. It is assumed that those who were finding it difficult to survive before the hurricane will want to return and continue the struggle. Many of the Okies and Arkies who fled the Dust Bowl in the 1930s never returned to their homes and farms. Instead they settled in the rich farming land of the San Joaquin Valley of central California, where they had more prosperous opportunities. Perhaps many of those who fled Katrina will also find better opportunities in the various states where they are now making an adjustment and forging a new life.

Schrems pointed out the development of the relief administration for disasters in the US. It is important to mention the transition of the Roosevelt's government to Keynesianism in the late 1930s. This governmental transition helped the Katrina migrants some decades later. But, Schrems did not mention the public health issues of the Dust Bowl migration e.g. Valley Fever virus /1/.

\section{Conclusions}

Strong, self-reliant people fled one region's drought, famine and failure in America's Dust Bowl of the 1930's to face serious health problems at their destination in California's Jan Joaquin Valley. In remarkable reporting of first-hand accounts in archived files, Christy and Garth (2015) describe health conditions of the dust bowl migrants. At the time, dysentery and diarrhea were widespread; agricultural migrants made up $90 \%$ of reported typhoid cases in one epidemic; and a migrant camp in the Valley reported 26 cases of smallpox. A quarter of the people in one San Joaquin Valley 
migrant camp were diagnosed with Valley fever (Kern County Health Department 1937). The first discovered cases of Valley Fever in California had only been reported some 40 years earlier. In the mid-1930's Valley Fever was still relatively unknown and misdiagnosed. The Dust Bowl migrants unwittingly fell into these conditions, where steps to avoid this relatively misunderstood disease were not followed. Displaced persons are often in this circumstance, where decisions must be made quickly, without the luxury of choice. Witness the new Syrian exodus to the "Promised Land" Europe. People are driven from their homelands, albeit over different circumstances, to seek shelter in environments, camps and cultures greatly different from their own. This paper reminds us that whether climate, war or discrimination is behind it, mass migration stresses community health and preparation is essential to reduce the consequences. Models of mass migration must account for these factors, and historical examples, such as these from the American Dust Bowl, offer valuable lessons.

\section{Notes}

/1/ The recent spread of the Zika virus is another case that deserves attention for migrations.

The Zika virus is a vector mosquito-borne virus and blood exchanged. Valley Fever is a mold borne and inhaled virus. Epidemics of Zika have been recorded in Africa, the Americas, Asia and the Pacific.

There is no specific treatment or vaccine currently available for Zika virus (WHO, 2016).

It is too early to ascertain the future impacts of spreading of such viruses, which seem to be springing up without prior warnings but public health and social alerts should become established for rapid response.

\section{Acknowledgements}

We are obliged to the C. E. Smith's epigone and Valley Fever expert D. Pappagianis for his hospitality at UC, Davis. We thank A.E. Andersson, P. Quinn, H. Stapp, K. Haynes, J. Galgiani, R. Cebula and A. Nicogossian for their pertinent comments.

\section{References}

Alchian, A. A. (1950). Uncertainty, Evolution, and Economic Theory. Journal of Public Economy, LVIII, 211-21. Arizona Department of Health Services (ADHS), (2012). Arizona Valley Fever Report 2007-2011. Phoenix, AZ.

Arizona Department of Health Services (ADHS). (2007). Valley Fever Annual Report. Available from: http://azdhs.gov/phs/ oids/epi/disease/valley-fever/documents/reports/valley-fever-annual-report- 2007.pdf.

Atkinson, A. (2008). Commemorating Richard Musgrave (1910-2007). Finanzarchiv, 64, 145-170.

Baggott, J. (2011). The Quantum Story. Oxford Univ. Press.

Becker G. S. (1962). Investment in Human Capital. Journal of Political Economy, 70, 9-49.

Bewley, T. F. (1981). A Critique of Tiebout's Theory of Local Public Expenditures. Econometrica, 49(3), 713-740.

Bickerdike, C. F. (1902). Taxation of Site Values. Econ. Journal, 12, 472-84.

Buchanan, J. (1975). Public Finance and Public Choice. National Tax Journal, 28(4), 383-394.

Cal/OSHA (California Division of Occupational Safety and Health) 2014, personal communication.

Cebula R. J. (1980). Voting with one's feet; A critique of the evidence. Regional Science and Urban Economics, 10, 91-107

Cebula, R. J. (1979). The determinants of human migration. Lexington, MA: Lexington Books.

Cebula, R. J. (2002). Migration and the Tiebout-Tullock Hypothesis Revisited. The Review of Regional Studies, 32(1), 87-96.

Cebula, R. J. (2009). Migration and the Tiebout Hypothesis Revisited. American Journal of Economics and Sociology, 68, 541-551.

Cebula, R. J., \& Alexander, G. (2006). Determinants of Net Interstate Migration, 2000-2004. Journal of Regional Analysis and Policy, 27(2), 116-23.

Centers for Disease Control and Prevention (CDC), 2001; Coccidioidomycosis in Workers at an Archeologic Site Dinosaur National Monument, Utah, June-July 2001; Morbidity and Mortality Weekly Report (MMWR), 50(45), 1005-1008.

Centers for Disease Control and Prevention (CDC). (1994). Coccidioidomycosis - California, 1991-1993. MMWR, 43(23), 421-423.

Christy, G., \& Garth, M. (2012). "A 'Flat, Tired People': The Health of California's Okies During the 1930s." Walter W. 
Stiern Library, California State University, Web.

Cole, G. T., et al. (2004). A vaccine against coccidioidomycosis is justified and attainable; Med Mycol., 42(3), 189-216.

Coleman J. S. (1966). Equality of Educational Opportunity. US Department of Health, Washington, DC.

Conway, K. S., \& Houtenvile, A. J. (2003). "Out with the Old, In with the Old: A Closer Look at Younger versus Older Elderly Migration,” Social Science Quarterly, 84(2), 309-328.

Conway, K. S., \& Houtenville, A. J. (1998). "Do the Elderly 'Vote with Their Feet'?” Public Choice, 97(1), 63-85.

Conway, K. S., \& Houtenville, A. J. (2001). "Elderly Migration and State Fiscal Policy: Evidence from the 1990 Census Migration Flows," National Tax Journal, 54(1), 103-23.

Coombs, C.K., Sarafoglou, N., \& Crosby, W. (2012). Property Taxation, Capitalization, and the Economic Implications of Raising Property Taxes. International Adv. Economic Res, 18, 151-161.

Crossen, C. (2005). Americans Who Fled Drought in the 1930s Found Little Sympathy. Wall Street Journal, Sept. 7.

Dalton, R. (2010). Palaeogenetics: Icy resolve. Nature, 463, 724-725.

Davis, L. (1998). Environmental Disasters. Facts on File.

Donaghy, K. P (2002). The "green book" twenty years on: A new look at the research program of Isard and Lossatos's .... Papers in Regional Science, 81, 499-509.

Dowding K. (2008). A Pandemonium of Confusions.... New Political Economy, 13, 335-348.

Dowding K. et al. (1994). Tiebout: A Survey of the Empirical Literature. Urban Studies, 31, 767-797.

Egan, T. (2006). The worst hard time. Houghton Mifflin.

Fischel, W. A. (2000). Municipal Corporations, Homeowners, and the Benefit View of Property Tax. Conference "Property Taxation and Local Government Finance", Arizona.

Fischel, W. A. (2006). The Tiebout Model at Fifty. Lincoln Institute of Land Policy. Cambridge.

Flaherman, V. S. et al. (2007). Estimating severe coccidioidomycosis in California. Emerging Infectious Diseases 13, 1087-1090.

Florida, R. (2002). The rise of the creative class. Basic Books.

Forsund, F. R., \& Sarafoglou, N. (2005). The Tale of the two Research Communities: The Diffusion of Research on Productive Efficiency. International Journal of Production Economics, 98(1). (Available online at www.sciencedirect.com).

Frisch, R. (1969). From Utopian Theory to Practical Applications. www.nobelprize.org.

Gale, L. R., \& Heath, W. C. (2000). "Elderly Internal Migration in the U.S. Revisited," Public Finance Review, 28(2), 153-7.

Galgiani J. N. et al. (2005). Coccidioidomycosis. Clin. Infect. Dis, 41, 1217-1223.

Galgiani, J. N. (2008) Vaccines to Prevent Systemic Mycoses: Holy Grails Meet Translational Realities; J. Infectious Diseases, 197, 938-40. http://dx.doi.org/10.1086/529205

Ghatak, S. et al., (1996). Migration theories and evidence: An assessment. Journal of Economic Surveys, 10(2), 159-198.

Gia, G. P. (2014). Dust Storms and Valley Fever 1874-2014. www.gillbertgia.com.

Grassmueck, G. (2011). What Drives Intra-country Migration: The Impact of Local Fiscal Factors on Tiebout Sorting. Review Regional Studies, 41, 119-138.

Graves P. E. (1980). Migration and Climate, Journal of Regional Science, 20(2), 227-237.

Greenwald, A. G. (2012). There is Nothing So Theoretical as a Good Method. Perspectives on Psychological Science, 7(2), 99-108.

Greenwood, M. (1975). Research on Internal Migration in the US: A Survey. Journal of Economic Literature, 13(2), 397-433.

Greenwood, M. (1985). Human Migration: Theory, Models, and Empirical Studies. Journal of Regional Science, 25(4), 521-544.

Greenwood, M. et al. (1991). New directions in migration research. Annals of Regional Science, 25, 237-270. 
Gregory, J. N. (1989). American exodus: the Dust Bowl migration and Okie culture in California. Oxford Univ. Press.

Haken, H. (1977). Synergetics, An Introduction. Springer.

Haynes K. E., et al. (1973). Inter-metropolitan migration in high and low opportunity areas. Economic Geography, 49, 68-73.

Hector, R. F. et al. (2011). Public health impact of coccidioidomycosis in California and Arizona. International Journal Environ. Res. Publ. Health, 8, 1150-1173.

Henderson, J. V. (1974). Sizes and the types of cities. American Economic Review, 64, 640-656.

Hicks, J. R. (1932). The Theory of Wages, Macmillan.

Hirschmann, J. V. (2007). The early history of Coccidioidomycosis: 1892-1945. Clin Infect Dis., 44(9), 1202-1207.

Holmberg, I., \& Sarafoglou, N. (1988). Study Case: Sweden, in W. Weidlich and G. Haag (eds): Interregional Migration, Dynamic Theory and Comparative Analysis, Springer-Verlag, Berlin.

Hospenthal, D. R. (2013). Coccidioidomycosis. Emedicine.medscape.com/article/215978-overview.

Hotelling, H. (1921). A Mathematical theory of migration (M.A. Thesis), republished in Environment and Planning A, (1978), 10 .

Huang, J. Y. (2012). Coccidioidomycosis-associated Deaths, United States, 1990-2008. Emerg. Infect. Dis., 18(11), $1723-1728$.

Huck, E. J. (2004). Tiebout or Samuelson: The 21st Century Deserves More. Marquette Law Review, 88(1), 16.

IPCC. (2007). Climate Change 2007: Synthesis Report. Contribution of Working Groups I, II and III to the Fourth Assessment Report of the Intergovernmental Panel on Climate Change. IPPCC, Geneva.

Isard W., \& Liossatos, P. (1979). Spatial Dynamics and Optimal Space-Time Development. North-Holland.

Isard, W (1960). Methods of regional analysis, MIT Press.

Kern County Health Department (1937). Annual Report, Fiscal Year July I, 1936 to June 30, 1937.

Koopmans T. (1979). Economics among the sciences. American Economic Review, 69, 1-33.

Laniado-Lavorin, R. (2007). Exanding understanding of epidemiology of Coccidioidomycosis in the Wstern hemisphere. Annals, N.Y. Academy of Science, 1111, 19-34.

Lee, E. S. (1966). Theory of Migration. Demography, 3, 839- 847.

Lejonhufvud, A. (1968). On Keynesian Economics and the Economics of Keynes. Oxford.

Lewin, K (1951). Field theory in social science (Edited by D. Cartwrite). Harper \& Row.

Lieber S. R. (1979) Experimental approach for the migration decision process. Tijdschrift voor Economische en Sociale Geografie, 70(2), 75-85.

Lindhall, E. (1919). Die Gerechtigkeit Der Besteuerund. Gleerup.

Mahler, A.-B., et al. (2006). Dust transport model validation using satellite- and ground-based methods in the southwestern United States; SPIE, 6299.

Mandell, S. (2001). Ground Leases \& Local Property Taxes. Memorandum 5:56, Royal Institute of Technology, Stockholm.

Margolis, J. (1955). A comment on the Theory of Public Expenditures. Review of Economics and Statistics, 32,347-349.

Marx, S. K., McGowan, H. A., \& Balz, K. S. (2009). Long-range dust transport from eastern Australia: a proxy for Holocene aridity and ENSO-type climate variability. Earth Planet. Sci. Lett. 282, 167-177.

McLeman R. A. et al. (2014). What we learned from the Dust Bowl: lessons in science, policy, and adaptation. Population and Environment, 35,417-440.

Merton R. K. (1968). The Matthew Effect in Science. Science, 159, 56-63.

Merton, R. C. (2006). Paul Samuelson and Financial economics. American Economist, 50(2), 9-31.

Mieszkowski, P., \& Zodrow, G. R. (1989). Taxation and the Tiebout model - The differential effects of head taxes, taxes on land rents, and property taxes. JEL, 27(3), 1098-1146.

Millimet, D. L. (2013). Environmental Federalism: A Survey of the Empirical Literature. IZA DP No. 7831.

Molho, I. (2013). Theories of Migration: A Review. Scottish Journal of Political Economy, 60(5), 526-556. 
Molloy, R. et al., (2011). Internal Migration in the US. NBER Working Paper, No. 17307.

Morain, S. A. et al. (2009). Public Health Applications in Remote Sensing: Final Benchmark Report. NASA Cooperative agreement NNS04AA19A.

Musgrave R. A., \& Peacock, A. (eds). Classics in the Theory of Public Finance. MacMillan.

Musgrave, R. A. (1959). The Theory of Public Finance. McGraw Hill.

Musgrave, R. A. (1959). The Theory of Public Finance. McGraw-Hill.

Musgrave. (1939). The Voluntary Exchange Theory of Public Economy. Quarterly J. of Economics, LII, 213-17.

Myers, N. (1979). Environmental refugees. Population and Environment, 19(2), 167-182.

Netzer, D. (1966). The Economics of the Property Tax, Brookings, Washington.

Oates W. E. (1969). The Effects of Property Taxes and Local Public Spending on Property values: An Empirical Study of Tax capitalization and the Tiebout Hypothesis. Journal of Political economy, 77(6), 957-971.

Oates W. E. (2006). The Many Faces of the Tiebout Model. In The Tiebout Model at Fifty, ed. W. A. Fischel, 21-45. Lincoln Institute of Land Policy. Cambridge, MA.

Oates, W. E. (1969). An essay on fiscal federalism. Journal of Economic Literature, 37, 1120-1149.

Ostrom, V., \& Ostrom, E. (1971). Public Choice: A Different Approach to the Study of Public Administration. Public Administration Review, 31(2), 203-216.

Pappagianis, D. (1994). Marked increase in cases of coccidioidomycosis in California: 1991, 1992, and 1993. Clin Infect Dis.; 19, S14-S18.

Pappagianis, D., \& Einstein, H. (1978). Tempest from Tehachapi takes toll or Coccidioides conveyed aloft and afar. West. J. Med. 129, 527-530.

Pickhardt, M. (2006). Fifty years after Samuelson's "The pure theory of public expenditure": What are we left with? The History of Economics Society, 28(4), 439-460.

Pigou, A. C. (1928). A Study in Public Finance. Macmillan.

Plato (2012). Republic. Penguin.

Potter, P. (2013). The Ecology of Wrath. Emerg. Infect. Dis, 19(10), 1713-1715.

Price, D. O., \& Sikes, M. M. (1975). Rural-urban migration research in the US. NIH, 75-565.

Quetelet, A. (1835). Essai de psysique sociale.

Ravenstein, E. G. (1885). The Laws of Migration. Journal of Royal Statistical Society, 48, 167-227.

Report. (2007-2011). Arizona Department of Health Services, Phoenix, AZ.

Ritchey, P. N. (1976). Explanations of Migration. Annual Review of Sociology, 2, 363-404.

Rosen, S. (1974). Hedonic and Implicit Markets- Product Differentiation in Pure Competition. Journal of Political Economy, 82, 34-55.

Samuelson, P. A. (1954). A pure theory of public expenditure. Review of Economics and Statistics, 36, 387-389

Samuelson, P. A. (1955). Diagrammatic Exposition of a Theory of Public Expenditures. Review of Economics and Statistics, 32, 350-356.

Samuelson, P. A. (1958). Aspects of Public Expenditure Theories. Review of Economics and Statistics, 40, 332-338.

Sarafoglou, N. (1987). A Contribution to Population Dynamics in Space. Dissertation. Umea Economic Studies No. 179, Umea University, Umea.

Sarafoglou, N., \& Kafatos, M. (2013). Infrastructure vulnerability and climate, in R. Pielke (ed). Climate Vulnerability, Elsevier, Amsterdam.

Sarafoglou, N., Kafatos, M., \& Beall, J. H. (2012). Simultaneity in Scientific Enterprise. Studies in Sociology of Science, 3(3), 20-30.

Schrems, S. (2010). The 1930s Dust Bowl and Katrina: Environmental Refugees. westernamericana2. blogspot.se.

Schultz, T. W. (1961). Investment in Human Capital. American Economic Review, 51(1), 1-17.

Simon, H. (1943). The Incidence of a Tax on Urban Real Property. Quarterly Journal of Economics, 57, 398-421. 
Sjaastad, L. A. (1962). The Costs and Returns of Human Migration. Journal of Political Economy, 70(5), 80-93.

Smith C.E. (1940). Epidemiology of acute coccidioidomycosis with erythema nodosum ("San Joaquin" or "Valley Fever"). Am. J. Pub. Health, 30, 600-611.

SollaPrice, D. de (1976). A general theory of bibliometric and other cumulative advantage processes. Journal of the American Society for Information Science, 27, 292-306.

Sondermeyer, G. et al., (2013). Coccidioidomycosis-associated hospitalizations, California, USA, 2000-2011. Emerg infect Dis. 19, 1590-1598.

Sprigg W. A. et al. (2012). Airborne Dust Models: A Tool for Environmental Health Tracking. CDC, Atlanta, GA.

Sprigg, W. A. (2008). Public health applications in remote sensing. http://spie.org/ x33688.xml?ArticleID=33688

Sprigg, W. A. (2012). Airborne Dust Models: A Tool in Environmental Health Tracking; final report, the US Centers for Disease Control and Prevention and the National Aeronautics and Space Administration's program in Applied Sciences for Health and Air Quality; CDC, Atlanta, GA, 180.

Sprigg, W. A. et al., (2014). Regional dust storm modeling for health services: The case of Valley Fever. Aeolian Research (forthcoming).

Sprigg, W. A., et al. (2012). Airborne Dust Models: A Tool in Environmental Health Tracking. Center for Disease Control and Prevention, CDC, Atlanta, GA.

Stauffer, S. A. (1940). Intervening Opportunities. American Sociological Review, 5, 845-867.

Stein, W. J. (1973). California and the dust bowl migration. Greenwood Press.

Steinbeck, J. (1939). The Grapes of Wrath. The Viking Press.

Stolper, W. F., \& Samuelson, P. A. (1941). Protection and Real Wages. Review of Economic Studies, 9, 58-73.

Tacoli, C. (2009). Crisis or adaptation? Migration and climate change in a context of high mobility. Environment \& Urbanization 21:513-525. http://dx.doi.org/10.1016/j.atmosenv.2006.10.061

Thurow, L. C. (1971). The Income Distribution as a Pure Public Good. Quarterly Journal of Economics, 85(2), 327-36.

Tiebout, C. N. (1956). A pure Theory of Local Expenditures. JPE, 64(5), 416-24.

Todaro, M. P. (1969). Model of Labor Migration and Urban Unemployment in LDCs. American Economic Review, 59, 138-148.

Translated in English (1958). "Just taxation-A positive solution" in Loftus, P. and B. McKay; 2014; Race is on for Ebola Drug; Wall Street Journal, October 18-19, 2014, CCLXV, 93.

Tsang, C.A., et al. (2010). Enhanced Surveillance of Coccidioidomycosis, Arizona, USA, 2007-2008; Emerg. Infect. Dis., 16(11).

Tullock, G. (1971). Public Decisions as Public Goods. JPE 79 Valleyfeversurvivor.com.

Weidlich W. (2000). Sociodynamics: a Systematic Approach to Mathematical Modelling in the Social Sciences. Harwood, Amsterdam.

Weidlich, W. (1991). Physics and social sciences- the approach of synergetics. Physical Reports, 204, 1-163

Weidlich, W., \& Haag, G. (1983). Concepts and Models of Quantitative Sociology, Springer.

World Health Organization. (2016). Zika virus fact sheet, Media Centre.

Yin, D., Nisckovic, S., \& Sprigg, W. A. (2007). The impact of using different land cover data on wind-blown desert dust modeling results in the southwestern United States. Atmos. Environ.

Zipf, G. K. (1949). Human Behavior and the Principle of Least Effort, Addison-Wesley.

Zuckerman, H. (1987). Citation analysis and the complex problem of intellectual influence. Scientometrics, 12, 329-338.

\section{(cc) BY}

This work is licensed under a Creative Commons Attribution 3.0 License. 